\title{
The user's perceptions of Perdana Botanical Garden in Kuala Lumpur
}

\author{
Hong Ching Goh* and Noratiqah Mahmood@Mahmud \\ Department of Urban \& Regional Planning, Faculty of the Built Environment, University of Malaya, \\ K.L.50603, Malaysia \\ *gohhc@um.edu.my
}

Public parks are often visualized as open spaces which encourage social interaction and are used for recreational purposes. In Malaysia, the planning of parks is based on the hierarchical planning standard requirement in accordance to the size of catchment area. Public parks at a smaller scale are provided in residential areas for the enjoyment of the neighborhoods. In larger cities such as Kuala Lumpur and Georgetown, urban parks do not only serve as the recreational areas for the residents; they are also tourism attractions, such as Perdana Botanical Garden in Kuala Lumpur, which was originally planned as an urban park in Kuala Lumpur. However, due to the dual uses for both recreation and tourism, conflicts may arise due to the different expectations by park users. This paper intends to reveal the user's perceptions about the role of Perdana Botanical Garden for recreational purpose. The findings revealed that the park users were satisfied with the activities and facilities offered in the park except the parking facilities especially when its location is not within the walking distance for most of the users. Further to that, it is revealed that the role of Perdana Botanical Garden as a tourism attraction has benefited the park users especially in terms of its management, maintenance and the activities created. Nonetheless, improvement in terms of parking facilities to accommodate the users came with private transportation and better accessibility for the tourists via public transportation mode must be adequately considered.

Keywords: Public parks, open spaces, recreation, tourism attraction, user's perception

\section{INTRODUCTION}

The significance of public parks contributing to the built environment and the quality of life in sustainable cities has received substantial recognitions (Maruani and Amit-Cohen 2007). Public parks provide opportunities to the urban population to participate in a range of recreational activities within a greener and more natural environment in the urban areas. They also play a very crucial role as a green lung in the highly populated urban area which contributes to the better air quality in the cities. Through these functions, public parks contribute to the promotion of public health as well as the well-being of a city. Despite of its importance, studies also show that attention to the provision and maintenance of public parks in urban areas is still poor (Tyrvainen and Vaanaen 1998). Furthermore, there is also low appreciation of green spaces reflected in the recent cuts in the maintenance of budget of many urban areas (Chiesura 2004). On the other hand, public parks in large cities which portray outstanding landscape features may become a tourism attraction, leading to the potential conflict of use between tourists and locals (Low et al 2005).

Perdana Botanical Garden is the oldest public park in Kuala Lumpur. The role of the park has evolved since its establishment from serving merely the local residents to becoming a tourism attraction in Kuala Lumpur. Furthermore, the park has changed its use from a public park to a botanical garden embedded within a larger tourism attraction, the Tun Abdul Razak Heritage Park in recent years. Whether this evolution has changed its functions as a public park is what this paper would like to find out. This paper identifies the perceptions among the park users in terms of its general management and maintenance, activities and facilities provided.

\section{LITERATURE REVIEW}

The emergence of urban parks can be traced back to the $19^{\text {th }}$ century, when the awareness of the needs for introducing natural assets and component in urban contexts were in the rise. The rising awareness was a respond to the rapidly increasing population in urban areas and the fast pace of urbanization when the industrial revolution started. In general, the creation and development of urban park movement aims to increase the quality of life in the modern city (Conway 1996; Pregill and Volkman 1999). Park planning movement started in England (Andersen 1969; Bolund and Hunhammar 1999) where Victoria Park is considered as the first urban park in the history while some authors who claimed that Birkenhead Park as the first urban park of which its construction was financed fully with public money (Tate 2004). The planning of parks has been closely related to urban and garden design 
(Eckbo et al 1993). The planning of urban park has evolved over the years, from the initial representation of rural landscape such as the Central Park in New York (Bolund and Hunhammar 1999; Costanza et al 1997) to the Amsterdamse Bos Park which adapts the ecological functions (Tate 2004) or the Park Andre-Citroen which adopted the formal design principles with ecological criteria and the recent movement of adapting the environmental education functions as presented in the City Park of Porto.

Urban parks are an important part of the complex urban ecosystem network. They provide significant ecosystem services (Loures et al 2007). This wide range of ecosystem services benefits the urban communities environmentally, aesthetically, psychologically, recreationally and economically (Burgess et al 1988; Conway 2000; Gehl and Gemzoe 2001; Grahn 1985).

Environmentally, urban areas are regarded as built environment which represents a high level of ecosystem intervention (Maruani and Amit-Cohen 2007). This intervention alters the landscape and interferes with natural processes. Urban parks on the other hand are generally recognized as a land use that features a relatively low level of intervention that allows continuous function of the ecosystems and survival of nature and landscape values. Subsequently, urban park planning is also regarded as a 'conservation effort' from extreme intervention or damage imposed by development. Due to the lesser invention and a great presence of trees, urban parks play an important role contributing to the sequestration of carbon dioxide emission and oxygen production in urban areas. They also provide other environmental benefits such as providing clean air through ameliorating the presence of pollutants from the air (Salazar and Menendez 2007) and water (Jo 2002), regulating micro-climate and reducing the noise (Bolund and Hunhammar 1999) generated by the construction and traffics in the urban areas. According to Solecki and Welch (1995), the community as a whole also benefits indirectly from the urban parks which serve as water retention areas for flood protection.

Aesthetically, parks offer an important amenity value for the urban population by decreasing the visual impact of a built environment dominated by asphalt and concrete (Salazar and Menendez 2007; Poudyal et al 2009). This aesthetic property of urban parks also contributes to psychological health especially in providing an effective antidote to the stress of urban living. The feelings and emotions evoked in the parks through contact with nature, the sense of refuge and freedom, relaxation and relief from stress (Maruani and Amit-Cohen 2007), have been regarded as a very important contributor for the well-being of many urban populations (Chiesura 2004).

Recreation is known as an activity that is engaged in during one's free time (Manning and More 2002). According to McCormack et al 2010, urban parks offer a wide range of leisure pursuits to the urban population (McCormack et al 2010). Engaging in recreation helps people to satisfy their motivations such as appreciating nature, learning about history and enhancing family togetherness (Brown and Haas 1980). Through this engagement, several benefits are produced at individual and societal level. For individuals, these include advances in physical and mental health, personal growth and development. At societal level, engaging in recreation helps to strengthen family bonding, enhancing community pride and reducing the social deviance. It also helps to increase productivity and reduce health costs from the economic point of view (Driver 1990; Driver 1996; Stein and Lee 1995; Allen 1996). Studies also suggest that access to nearby parks and natural settings is associated with improved mental health (Payne et al 2005), positive affect and reduce anxiety (More and Payne 1978), better physical health through high level of physical activity (Payne et al 2005) and healthy weight among children (Potwarka et al 2008).

Loures et al (2007) also stressed the linkage between urban parks and human health issues. According to scholars, parks provide children the simple joys of playing in the park, improving health and recreation, promote cultural and social values (Vos and Klinj 2002) which eventually, leading to sustainable city planning. Social value is concerned with how places encourage people to interact in ways which lead to trust, mutual understanding, shared values and supportive behavior (Loures et al 2007). Urban population access the parks to experience nature and for recreation. Nature and recreation become the common interest where the park users connect and interact with each other (Hayward and Weitzer 1984). People get connected and meet new friends by using urban parks which subsequently leads to social cohesion (Peters et al 2010; De Haan 2005; Maruani and Amit-Cohen 2007).

Educational and scientific services are increasingly important in urban parks. Urban parks offer a range of opportunities to stay and explore its biotic and abiotic elements, both for the students and researchers at all educational levels Solecki and Welch (1995).

Economically, urban parks also offer small business contracts to the urban population. Further to that, it has been in the rise that many urban parks are also the attractions for urban tourists. 
Table 1: Key features of Perdana Botanical Garden

\begin{tabular}{|c|c|c|}
\hline 1. & $\begin{array}{l}\text { Forest tree } \\
\text { collection }\end{array}$ & $\begin{array}{l}\text { The botanical garden showcases a good sampling of the tropical rainforest } \\
\text { species. }\end{array}$ \\
\hline 2. & $\begin{array}{l}\text { Plumeria tree } \\
\text { collection }\end{array}$ & $\begin{array}{l}\text { There is a unique collection of old Plumeria trees which are very famous for } \\
\text { creating exotic landscapes. }\end{array}$ \\
\hline 3. & Waterfall & Waterfall is a new feature in the botanical garden along Jalan Tembusu. \\
\hline 4. & Fernarium & $\begin{array}{l}\text { The garden has a collection of about } 100 \text { species of ferns found in Malaysia, } \\
\text { which spans the entire length of the boardwalk (jungle floor). }\end{array}$ \\
\hline 5. & $\begin{array}{l}\text { Zingiberales } \\
\text { Collection }\end{array}$ & The collection here consists of Gingers species of Costus and Musa. \\
\hline 6. & Decking & $\begin{array}{l}\text { There are two decking areas that provide a panoramic view of the garden, i.e. } \\
\text { boardwalk under the shade of Tembusu trees and another decking adjacent to } \\
\text { the Brazil Nut tree. }\end{array}$ \\
\hline 7. & Heliconia Garden & The Heliconia collection in this garden consists of both the species and hybrids. \\
\hline 8. & $\begin{array}{l}\text { Waterfall and fish } \\
\text { pond }\end{array}$ & $\begin{array}{l}\text { The waterfall and fish pond are located at the edge of the Heliconia Garden } \\
\text { which provide the park visitors a place to relax. }\end{array}$ \\
\hline 9. & $\begin{array}{l}\text { Unusual species } \\
\text { collection }\end{array}$ & $\begin{array}{l}\text { The collection of unusual trees around the world is found in the square of } \\
\text { Laman Perdana. Among them are the Adansonias and Moringas of Africa. }\end{array}$ \\
\hline 10. & Amphitheatre & $\begin{array}{l}\text { The amphitheatre was built in the late 1960s. It was famous for providing free } \\
\text { entertainment to the general public. It was named as 'Pangung Anniversari' and } \\
\text { was once a famous performance stage for many local pop musicians and rock } \\
\text { stars. Today, the refurbishment of the amphitheatre has been completed with } \\
\text { roofs attached to it providing comforts to the visitors. }\end{array}$ \\
\hline 11. & $\begin{array}{l}\text { Rare Fruit Trees } \\
\text { Collection }\end{array}$ & $\begin{array}{l}\text { The collection of rare fruit trees (e.g. Garcinia cambogia) is found at the slopes } \\
\text { to the Tun Abdul Razak Memorial. }\end{array}$ \\
\hline 12. & Laman Perdana & $\begin{array}{l}\text { The Laman Perdana features majestic trees such as Adasonias and Moringas and } \\
\text { Eucalyptuses. }\end{array}$ \\
\hline 13. & Topiary Collection & A cluster of topiary here is from Streblus asper. \\
\hline 14. & Cycad Island & $\begin{array}{l}\text { Cycab Island is a man-made island which houses the cycab collection, bamboo } \\
\text { as well as grass collections. }\end{array}$ \\
\hline 15. & Sunken Garden & $\begin{array}{l}\text { This garden houses Acalypha siamensis, andLoropetalum chinense shrubs } \\
\text { with addition of flowering annuals on the slopes. }\end{array}$ \\
\hline 16. & Conservatory & $\begin{array}{l}\text { In the past, most of the herbaceous collections are housed in Conservatory in the } \\
\text { late } 19^{\text {th }} \text { century. The conservatory area now features a typical tropical garden } \\
\text { with geraniums, aroids and other foliages plants. }\end{array}$ \\
\hline 17. & $\begin{array}{l}\text { Trees Naming } \\
\text { Places }\end{array}$ & $\begin{array}{l}\text { There are trees that take after the name of places or areas in Malaysia, as big as } \\
\text { the state names such as Malacca or Johore, or small areas such as Padang } \\
\text { Bungor or Sentul. }\end{array}$ \\
\hline 18. & Herb Garden & $\begin{array}{l}\text { The Herb Garden features the various cultures of the tropical regions through } \\
\text { the herbs commonly planted and used in people's everyday lives, both in } \\
\text { culinary and traditional medicine practices. }\end{array}$ \\
\hline 19. & Brownea Street & $\begin{array}{l}\text { This street is named after the rows of Brownea trees along the newly upgraded } \\
\text { pathway. }\end{array}$ \\
\hline 20. & Deer Park & $\begin{array}{l}\text { The KL Deer Park covers an area of } 2 \mathrm{ha} \text { and houses a few species of deer } \\
\text { including the fallow deer, axis deer, sambar deer as well as the mouse deer or } \\
\text { chevrotain, which is known to be the world's smallest hoofed animals. }\end{array}$ \\
\hline 21. & Hibiscus Park & $\begin{array}{l}\text { The park features several species of Malaysia's national flower. Other } \\
\text { attractions within the park are a } 4 \mathrm{~m} \text { high waterfall, pools and fountains. } \\
\text { There is also a colonial style building that has been converted into an } \\
\text { exhibition hall equipped with a tearoom and a gallery. }\end{array}$ \\
\hline 22. & Orchid Garden & $\begin{array}{l}\text { There are more than } 800 \text { species of orchids found in this garden. There is a semi } \\
\text { circle pergola for the climbing, epiphytic variety and a rock garden for the } \\
\text { terrestrial variety. }\end{array}$ \\
\hline
\end{tabular}




\section{METHODS}

This study employed a case study approach, drawing upon the quantitative method in primary data collection using visitor questionnaire survey. A total of 100 samples were collected from each park through random sampling assisted by two enumerators. Respondents were approached at the sitting and resting areas within the parks. In order to capture wider range of park users, the survey was conducted in the morning, noon and late afternoon during the weekends when most users visited the parks. The key features in the botanical garden are shown in Table and its distribution is shown in Figure 1.

In general, the questionnaire was divided into three sections. The first section aimed to collect data on the park's level of usage among its users and the second section sought to reveal the level of satisfaction among the users. The last section gathered the demographic profile of the users.

Data was then analyzed using IBM SPSS version 21. Analysis findings were presented using frequencies and percentage, which are presented and discussed in the following sections.

\section{Case study at a glance-Perdana Botanical Garden}

Established in 1888, Perdana Botanical Garden (PBG) is the first public park in Kuala Lumpur. It covers a land area of 91.6 hectares and is better known as Lake Gardens among the locals. Originally designed as a large-scale recreational park, PBG has been gradually turned into botanical garden over the years. Over the years, its name has changed from Public Gardens in the early days, to Lake Gardens and was renamed Taman Tasik Perdana in 1975 and latest in 2011, as Perdana Botanical Garden.

Today, Perdana Botanical Garden is part of the Tun Abdul Razak Heritage Park which consists of the following attractions: -

1. Parks and gardens- PBG which include the Deer Park, Orchid Garden, Hibiscus Garden; Bird Park and Butterfly Park

2. Museums- Islamic Art Museum, National Museum, Royal Malaysian Police Museum

3. History- Memorial Tun Abdul Razak, National Mosque, Tugu Negara (National Monument)

4. Others- Panggung Anniversari, National Planetarium

Due to its strategic location within the city center and its surrounding landmarks such as National Museum of Malaysia and Malaysian Houses of Parliament as well as the easy accessibility via public transportation, PBG is not only popular among the locals but also the international tourists visiting Kuala Lumpur. Due to its size, various transportation modes are provided to facilitate the exploration in the park. For instance, bicycles are available for visitors to explore the park apart from the shuttle trams which are available daily from $9 \mathrm{am}$ to $6 \mathrm{pm}$. Boats are also available for rental. Guided walks are also available at no cost on workdays from $8 \mathrm{am}$ to $10 \mathrm{am}$. Alternatively, private tours can be arranged for free with at least seven days advanced booking.

\section{RESULTS}

\section{Park user demographic profile}

A total of 100 respondents participated in the questionnaire survey where the females consist of $48 \%$ of total respondents and $52 \%$ were male respondents. In terms of marital status, $57 \%$ of the respondents were single while $43 \%$ were married. $62 \%$ of the respondents lived within Kuala Lumpur metropolitan area, while another $32 \%$ lived outside the metropolitan area (including those from other states within Peninsular Malaysia) and $6 \%$ of the respondents were not Malaysian. The last category of the respondents was tourists who were on holidays.

Relatively, majority of the respondents were young, where $66 \%$ aged 30 years old or below. $24 \%$ aged between $31-40$ years old and $10 \%$ aged above 40 years old. Majority of the respondents obtained high educational qualification. $57 \%$ of the respondents were diploma or degree holders, $31 \%$ had at least ' $O$ level' qualification. Another 12\% choose not to disclose their educational qualification.

\section{Visiting profile}

$38 \%$ of the respondents visited the park with their family members, followed by with friends (29\%), with couple/spouse $(17 \%)$, alone $(13 \%)$ and group (3\%). Of this, two-third of the visitors $(67 \%)$ came by their own transport while $25 \%$ reached the park via public transportation. The rest of the respondents $(8 \%)$ came by tour bus/vehicle.

$41 \%$ of the visitors came to the park during weekends while another $40 \%$ would drop by any time when they would like to participate in leisure activities. $3 \%$ visited the park on daily basis while $9 \%$ visited during school holidays and $6 \%$ came whenever there were special events in the park.

$34 \%$ of the respondents were in the opinion that the natural environment is the most appealing attraction in the park while another $33 \%$ gave 
credits to the overall landscape, another $21 \%$ referred to its flora and fauna and $10 \%$ highlighted the offered activities in the park.

One-third of the visitors came to the park to enjoy the beautiful nature while $32 \%$ came for recreational purpose. Another $16 \%$ came for picnic while $12 \%$ came for jogging. Interestingly, $4 \%$ of the respondents visited the park for research and educational purpose.

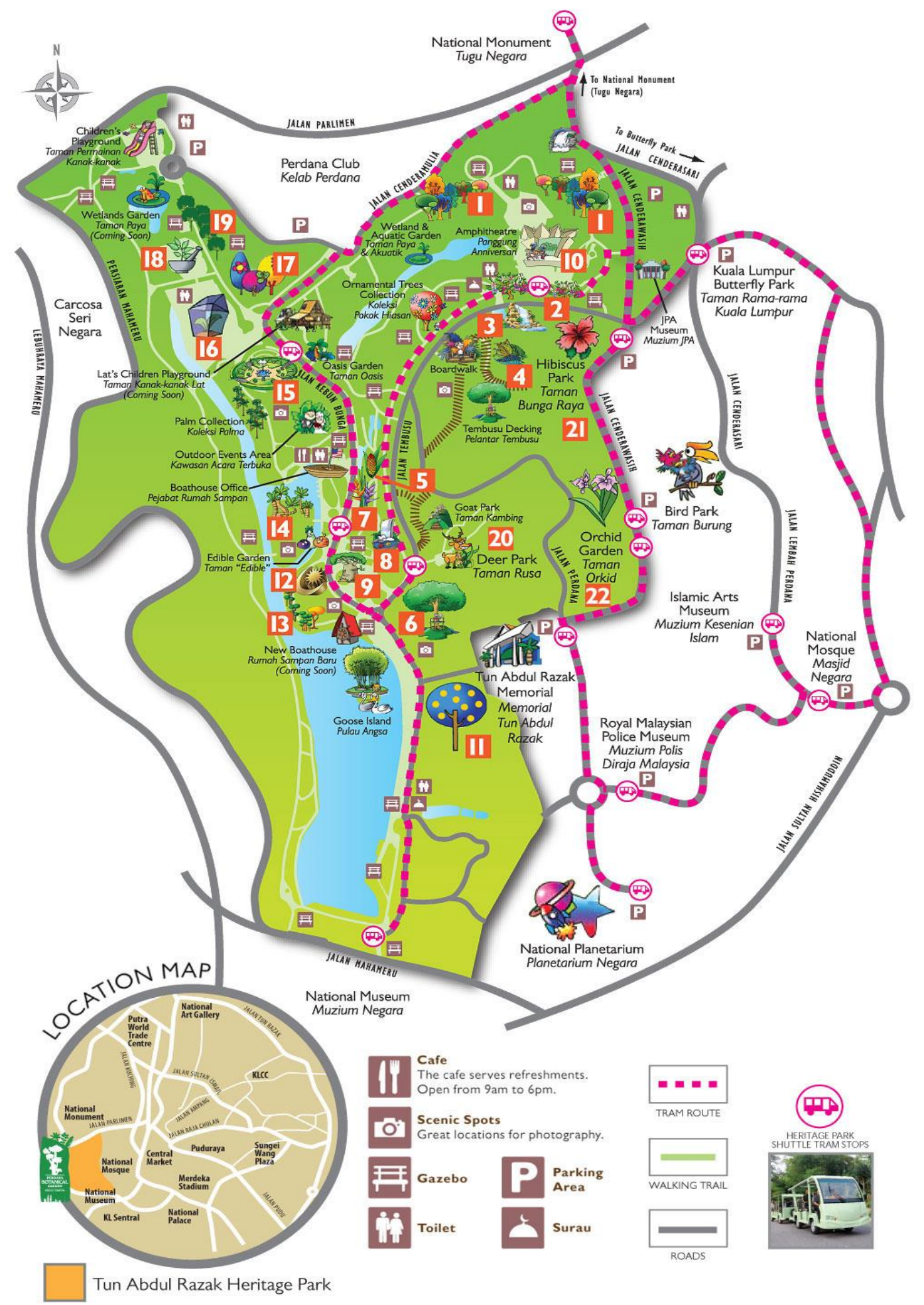

Figure 1: Layout plan of Perdana Botanical Garden 
Table 1: Visitor perceptions about Perdana Botanical Garden

\begin{tabular}{|c|c|c|c|c|}
\hline Visitor perceptions & $\begin{array}{c}\text { Strongly } \\
\text { disagreed }\end{array}$ & Disagreed & Agreed & $\begin{array}{c}\text { Strongly } \\
\text { agreed }\end{array}$ \\
\hline \multicolumn{5}{|l|}{ Overall perception } \\
\hline The park maintains a good level of management. & $8 \%$ & $8 \%$ & $60 \%$ & $24 \%$ \\
\hline It is comfortable to visit the park during weekends. & $4 \%$ & $6 \%$ & $57 \%$ & $33 \%$ \\
\hline The park is clean. & $1 \%$ & $9 \%$ & $58 \%$ & $32 \%$ \\
\hline The park is safe to be visited. & $3 \%$ & $15 \%$ & $49 \%$ & $33 \%$ \\
\hline \multicolumn{5}{|l|}{ Park location and accessibility } \\
\hline The park is located within a strategic location. & $10 \%$ & $58 \%$ & $20 \%$ & $12 \%$ \\
\hline $\begin{array}{l}\text { There is an adequate level of accessibility using } \\
\text { public transportation to the park. }\end{array}$ & $35 \%$ & $31 \%$ & $24 \%$ & $10 \%$ \\
\hline \multicolumn{5}{|l|}{ Activities offered in the park } \\
\hline $\begin{array}{l}\text { The park is suitable for recreational uses by all age } \\
\text { groups. }\end{array}$ & $2 \%$ & $10 \%$ & $58 \%$ & $30 \%$ \\
\hline $\begin{array}{l}\text { The park offers harmonious natural environment for } \\
\text { relaxation. }\end{array}$ & $3 \%$ & $2 \%$ & $50 \%$ & $45 \%$ \\
\hline The park offers more passive activities. & $3 \%$ & $18 \%$ & $40 \%$ & $39 \%$ \\
\hline $\begin{array}{l}\text { There are a wide range of attractions to visit in the } \\
\text { park. }\end{array}$ & $1 \%$ & $5 \%$ & $57 \%$ & $37 \%$ \\
\hline $\begin{array}{l}\text { The park offers informative and educational } \\
\text { experience through the activities and signboards. }\end{array}$ & $12 \%$ & $17 \%$ & $47 \%$ & $24 \%$ \\
\hline \multicolumn{5}{|l|}{ Facilities available in the park } \\
\hline $\begin{array}{l}\text { The number of food kiosk facility in the park is } \\
\text { adequate. }\end{array}$ & $27 \%$ & $44 \%$ & $17 \%$ & $12 \%$ \\
\hline $\begin{array}{l}\text { The parking facility provided in the park is } \\
\text { sufficient. }\end{array}$ & $45 \%$ & $39 \%$ & $10 \%$ & $6 \%$ \\
\hline $\begin{array}{l}\text { The resting area provided in the park is adequate and } \\
\text { comfortable. }\end{array}$ & $1 \%$ & $8 \%$ & $60 \%$ & $31 \%$ \\
\hline The number of sign boards in the park is adequate. & $5 \%$ & $20 \%$ & $58 \%$ & $17 \%$ \\
\hline $\begin{array}{l}\text { There is sufficient number of praying facilities } \\
\text { provided in the park. }\end{array}$ & $1 \%$ & $22 \%$ & $62 \%$ & $15 \%$ \\
\hline
\end{tabular}

Despite not being part of the botanical garden, the KL Bird Park and Butterfly Park were the most appealing attractions according to the respondents. This is due to both parks close proximity to the garden and status as part of the Tun Abdul Razak Heritage Park. $25 \%$ of the respondents quoted KL Bird Park as the most appealing attraction. This is then followed by Butterfly Park (20\%), Deer Park (19\%), Hibiscus Park (16\%), Orchid Garden (9\%), and Herbal Garden (7\%).

\section{Visitor perceptions about Perdana Botanical Garden}

The visitor perceptions of Perdana Botanical Garden were obtained through four categories, i.e. (1) the overall management, cleanliness, safety and the general use of park, (2) park location and accessibility, (3) activities offered in the park and lastly, the facilities available in the park (Table 1). The respondents were satisfied with the park management where $84 \%$ agreed that the park is well-maintained with a good level of management.

In particular, $90 \%$ of the respondents agreed that the park is clean and $82 \%$ were in the opinion that the park is safe. Similarly, $90 \%$ agreed that weekends were good time to visit the park because the park is not overcrowded during the weekends.

The respondents indicated the large size of the park and its zoning of activities was effective to create a leisurely environment for its users.

In terms of the park's location and accessibility, it is found that $68 \%$ of the respondents were unhappy with the location of the park. Despite 
knowing that it is impossible to change its location, respondents indicated the difficulty to reach the park via public transportation and they had to drive to the park. This indication is supported by the fact that only $34 \%$ of the respondents agreed that there is an adequate level of accessibility to the park via public transportation network. According to the respondents, it was also impossible to reach the park by walking due to its location within the city center and its surrounding land uses that are dominantly institutions and national landmarks.

$88 \%$ of the respondents agreed that Perdana Botanical Garden offered a wide range of activities which are suitable for recreational use by all age groups. $95 \%$ of the respondents were also in the opinion that the park offers harmonious natural environment for relaxation. $94 \%$ of the respondents agreed that wide ranges of attractions are offered in the park. $79 \%$ of the respondents agreed that the park offers more passive activities compared to active activities. $71 \%$ of the respondents also agreed about the informative and educational experience are offered in the botanical garden through activities and signboards.

In terms of the facilities available, food kiosks and parking facility were the major concerns among the respondents. Only $29 \%$ of the respondents agreed that the number of food kiosks available in the park is adequate. Similarly, only $16 \%$ of the respondents were in the opinion that the parking facility is sufficient. On the other hand, $75 \%$ of the respondents agreed that the signboards are clear and sufficient to provide directional guide in the park and $77 \%$ of the respondents were in the opinion that the existing praying facilities in the park is sufficient.

Lastly, the respondents were asked whether or not the Perdana Botanical Garden being a tourism attraction has an impact on their routine use of the park. Nearly $60 \%$ of the respondents who were locals were in the opinion that the presence of tourists does not affect their daily routine. Instead, they were proud that Perdana Botanical Garden is a tourism attraction in which they can enjoy the park with better quality especially in terms of its activities and maintenance. Furthermore, the number of users in the garden has been under control and carefully regulated.

\section{Suggestions for improvement}

Despite of the overall positive perceptions about the botanical garden, there were suggestions highlighted by the respondents for further improvements of the garden as follows: -

\begin{tabular}{|l|l|c|}
\hline No & \multicolumn{1}{|c|}{$\begin{array}{c}\text { Areas for } \\
\text { improvement }\end{array}$} & Percentage \\
\hline 1. & Parking facility & $12 \%$ \\
\hline 2. & Sign boards & $3 \%$ \\
\hline 3. & Recreational activities & $3 \%$ \\
\hline 4. & Informative staff & $5 \%$ \\
\hline 5. & Food kiosks & $7 \%$ \\
\hline 6. & Resting area & $6 \%$ \\
\hline 7. & Dustbins & $4 \%$ \\
\hline 8. & $\begin{array}{l}\text { Public transportation } \\
\text { mode }\end{array}$ & $7 \%$ \\
\hline
\end{tabular}

Parking facilities were deemed insufficient in Perdana Botanical Garden. 12\% of the respondents were in the opinion that the parking lots should be increased to accommodate park users. Apart from parking facilities, respondents also indicated that the number of food kiosks should be increased and the existing public transportation mode to the park should be improved. This was significant for the foreign visitors to the park who used the public transport. According to them, the tropical hot climate and humidity were the main constraint $\mathrm{s}$ to take the train to the nearest station and walk to the park. Meanwhile, the taxi fare was not cheap for them as they were travelling on budget. As for the food kiosks, $7 \%$ of the respondents who were all local visitors stated that the limited number of food kiosks had prevented them from staying longer in the park as many of them came with family members especially with children and they would like to buy some foods while spending longer time in the botanical garden.

Resting areas were highlighted by $6 \%$ of the respondents to be an area that requires improvement. According to the respondents, the number of resting areas should be increased and they should be in the form of covered sitting areas distributed in each garden in order to enhance the appreciation among the park users in each other. It was also important due to the hot and humid climate in Kuala Lumpur.

There were also $3 \%$ of the respondents who were in the opinion that the range of the recreational activities in the botanical garden can be diversified to attract the park users to spend longer time. On the other hand, the feedback on the informative staff was related to the signboards. 5\% of the respondents indicated that there should be more staff in the park to provide information, suggestions and guidance to the park users. According to them, there were workers in the park but they were merely the workers to water the gardens and may not be able to provide any useful information about the park. 
This comment also led to the similar group of respondents (3\%) who indicated the need to improve the signboards in the park. For them, it was important to improve the quality and quantity of the signboards in the park, not only to place the signboards at strategic locations, but also to provide informative guidance to the park users in an interesting way. This would indirectly enhance the educational components of general public and at the same time, improve the knowledge among the users of the botanical gardens. $4 \%$ of the respondents indicated the need to place more dustbins at strategic locations within the botanical gardens. Although they were in the opinion that the botanical garden is generally clean, it was inconvenient for them to look for the limited numbers of dustbins placed in the gardens.

\section{DISCUSSIONS}

Today, the entire Kuala Lumpur city is fully urbanized. Subsequently, the role of Perdana Botanical Garden which is managed by the Kuala Lumpur City Hall becomes increasingly important not only because of its function as 'open space' but also because it is opened to public at no cost.

Overall, the botanical garden was well perceived by the users. The overall management including the safety and cleanliness aspects of the garden was rated highly by the respondents. This is because of the role of Perdana Botanical Garden which no longer only serves as a public park per se but also as a tourism attraction in the country, Kuala Lumpur in particular. For that, the local daily users of the botanical garden lbenefited from the well-kept park condition due to its function in promoting tourism. Furthermore, the respondents also positively responded to the crowd level in the botanical garden even during the weekends which normally crowds would appear. One of the concerns in a public park is about the conflict generated by the tourist crowds in the park which would create annoyance to the daily park users, which in this case, did not happen. This is also closely due to the fact that the botanical garden is huge in size, and the tourists visiting botanical garden may not only concentrate in the botanical garden but to other attractions within the Tun Abdul Razak Heritage Park.

Similarly, activities offered in the botanical garden were well perceived by the respondents. These include the aspects of the suitability of the recreational activities, the natural environment within the gardens and the attractiveness of the gardens which meet the role in providing environmental and recreational benefits to urban communities. The respondents were also in the opinion that the botanical garden offered more passive activities to the users. This is well received by the respondents instead of negatively, mainly because the respondents already expected the passive activities to be carried out in the general setting of a 'botanical garden'. This is also related to the setting of Perdana Botanical Garden as a part of the Tun Abdul Razak Heritage Park which provided a clear zoning for different uses according to the activities and attractions. For that, the aesthetical and psychological benefits were fulfilled. On the other hand, the park's location and accessibility became the major concerns among the respondents who were mainly the locals. This is directly associated with the mode of transportation used by the local respondents (both within Kuala Lumpur metropolitan area and outside the metropolitan area) to the botanical garden, i.e. own transport. Relatively, less negative feedback was obtained among the foreign visitors who came to the park using the private transport arranged by the tour agency they have booked. As for the independent travelers, the location of the park was not friendly to them due to the distance and inconvenience using the public transportation such as buses and light rail transit.

Similarly, based on the feedback, the facilities provided in the botanical garden also required improvement, especially in the areas of food kiosks available and the parking lots provided in the park. For the food kiosks, it was revealed that families would like to spend longer time in the botanical garden but had to leave the garden for better choice of goods. The provision of better eatery service would enhance the economic benefits of the garden. Apart from that, most of them would not like to come back mainly due to the insufficient parking lots available. Resting areas were also deemed insufficient both in terms of the adequacy and comforts.

The number of signboards and more educational information were in the list for improvement. This may be closely related to the demographic profile of the respondents whom the majority was young respondents with relatively high educational qualification. The combined young and high educational groups expected better educational and learning experience in the botanical garden.

Perdana Botanical Garden is centrally located within the city center, making it reachable and enjoyable by both the locals and the tourists. Further to that, due to its importance as a tourism attraction, the botanical garden is well-maintained which benefits the locals who used the botanical garden on a daily basis. Yet, there are always the double sides of a coin. Its location also created an issue with accessibility as highlighted by the 
respondents, especially when the parking facilities were unable to cater for the increasing demand.

\section{CONCLUSION}

Perdana Botanical Garden has been an important icon in the history of public parks in the country and specifically for Kuala Lumpur. Its evolving role from a public park into a botanical garden also marked a change in the use of the park and the users that it attracted. So far, the botanical garden is able to maintain its quality in management and maintenance of the park. Yet, with the increasing demand from the users, it is important for the park management to consider the shortage of parking facilities (also in compensation to the relatively limited public transportation mode) as well as to consider increasing the number of food kiosks within the botanical garden. This is deemed necessary in considering of the size of the botanical garden and if the park management would like to encourage users to stay longer in the park both for the enjoyment and for educational purpose. This is interesting especially when some respondents indicated that they were in the botanical garden for educational and research purposes. More recreational activities and more covered sitting places would help to support the mission of the botanical garden, both for enjoyment and educational purpose. Other areas of improvement, despite being less significant and highlighted by the respondents, should be given due consideration by the park management in future in light of the increasing number of users to the park. While the paper was prepared, the visitor centre which is supposed to be built in the Phase 2 of the project was yet to come up, which should be able to enhance the park users experience in the botanical garden where more interactive and informative experiences are expected.

\section{REFERENCES}

Andersen, W. (1969). The Industrialization of Europe. Lisboa: Editorial verbo.

Bolund, P., Hunhammar, S. (1999). Ecosystem services in urban areas. Ecological Economics, 29, 293-301.

Burgess, J., Harrison, C., Limb, M. (1988). People, parks and the urban green: a study of popular meanings and values for open spaces in the city. Urban Studies, 25, 455473.

Chiesura, A. (2004). The role of urban parks for the sustainable city. Landscape and Urban Planning, 68, 129-138.

Conway, H. (1996). Public Parks. Buckinghamshire: Shire Publications Ltd.
Conway, H. (2000). The Regeneration of Public Parks. In J. Woudstra, Fieldhouse, K. (Ed.), Parks and people: the social functions.

Costanza, R., d'Arge, R., de Groot, R., Farber, S., Grasso, M., Hannon, B., Laskin, R., Sutton, P. and Van den Belt, M. (1997). The value of the world's ecosystem services and natural capital. Nature, 387, 253-260.

De Haan, H. J. (2005, 14-15 October 2005). Social and material appropriation of neighborhood space: collective space and resistance in Dutch urban community. Paper presented at the International Conference, Delft, Delft University of Technology, OTB, Delft.

Deane, P. (1979). The First Industrial Revolution. New York: Cambridge University Press.

Eckbo, G., Kiley, D. and Rose, J. (1993). Modern Landscape Architecture: a critical Review. In M. Treib (Ed.), Landscape Design in the Urban Environment. Cambridge: MIT Press.

Gavin R. McCormack, M. R., Ann M. Toohey, Danica Hignell. (2010). Characteristics of urban parks associated with park use and physical activity: A review of qualitative research. Health and Place, 16, 712-726.

Gehl, J., Gemzoe, L. (2001). New City Spaces. Copenhagen: Danish Architectural Press.

Grahn, P. (1985). Man's Needs for Urban Parks, Greenery and Recreation. Alnarp: Swedish Agricultural University.

Hayward, D., Weitzer, W.,. (1984). The public image of urban parks: past amenity, present ambivalence, uncertain future. Urban Ecology, 8, 243-268.

Jo, H. (2000). Impacts of urban greenspace on offsetting carbon emissions for middle Korea. J. Environmental Management, 64, 115-126.

Karin Peters, B. E., Arjen Buijs. (2010). Social interactions in urban parks: Stimulating social cohesion? Urban Forestry and Urban Greening, 9, 93-100.

Low, S., Taplin, Dana and Scheld, Suzanne. (2005). Rethinking urban parks: Public space and cultural diversity. Texas: University of Texas Press.

Luis Loures, Raul Santos, \& Thomas Panagopoulos. (2007). Urban Parks and sustainable city planning- the case of Portimao, Portugal. Paper presented at the WSEAS Transactions on Environment and Development.

Maruani, T., \& Amit-Cohen, I. (2007). Open space planning models: A review of approaches and methods. Landscape and Urban Planning, 81, 1-13. 
More, T., Payne, B. (1978). Affective responses to natural areas near cities. Journal of Leisure Research, 10, 7-12.

Neelam C. Poudyal, Donald G. Hodges, \& Christopher D. Merrett. (2009). A hedonic analysis of the demand for and benefits of urban recreation parks. Land Use Policy, 26, 975-983.

Payne, L., Orsega-Smith, E., Roy, M., Godbey, G. (2005). Local park use and personal health among older adults: an exploratory study. Journal of Park and Recreation Administration, 23, 1-20.

Potwarka, L. R., Kaczynski, A.T., Flack, A.L. (2008). Places to play: association of park space and facilities with healthy weight status among children. Journal of Community Health, 33, 344-350.

Pregill, P., Volkman, N. (1999). Landscapes in History- Design and Planning in the Eastern and Western Traditions: John Wiley \& Sons.

Robert Manning, \& Thomas More. (2002). Recreational values of public parks. The George Wright Forum, 19(2), 21-30.
Salvador del Saz Salazar, \& Leandro Garcia Menendez. (2007). Estimating the nonmarket benefits of an urban park: Does proximity matter? Land Use Policy, 24, 296-305.

Tate, A. (2004). Great City Parks. New York: Spon Press.

Tseira Maruani, \& Irit Amit-Cohen. (2007). Open space planning models: A review of approaches and methods. Landscape and Urban Planning, 81, 1-13.

Tyrvainen, L., Vaananen, H. (1998). The economic value of urban forest amenities: an application of the contingent valuation methods. Landscape and Urban Planning, 43, 105-118.

Vos, W., \& Klinj, J. (2002). Trends in European Landscape Development: prospects for a sustainable future. Wageningen: Kluwer Academic Publishers.

William D. Solecki, \& Welch, J. M. (1995). Urban parks: Green spaces or green walls. Landscape and Urban Planning, 32, 93106. 